\title{
APPLICATION OF PHOTOVOLTAIC SYSTEMS MINI COURSES IN THE SCHOOLS
}

\author{
Daniel Rodrigues Ferraz Izario \\ University of Campinas \\ Campinas/SP, Brazil \\ http://lattes.cnpq.br/9174775045358016 \\ Yuzo lano \\ University of Campinas \\ Campinas/SP, Brazil \\ http://lattes.cnpq.br/1819902045004845 \\ João Luiz Brancalhone Filho \\ National Telecommunications Institute \\ Santa Rita do Sapucai/MG, Brazil \\ https://orcid.org/0000-0001-9086-3915 \\ Karine Mendes Siqueira Rodrigues Ferraz Izario \\ Educational Anhanguera \\ Indaiatuba/SP, Brazil \\ https://orcid.org/0000-0001-9848-7029
}

\begin{abstract}
In the present time, photovoltaic systems, in the Brazilian and global perspectives are one of the most promising technologies to the future as it's clean, renewable, abundant and free, considering the sun as source. The society itself often rejects its benefits in the generation of electricity, being used as source of energy just recently in domestic appliances. There are both, the lack of information about its operation as well as the high operational costs, who is often responsible for acceptance problems. The youth is considerate the best way of getting rid of established stigmas though, spreading more clear information about the technology with initiatives such as mini courses in the school curriculum, enabling the student a better understanding about the photovoltaic modules as well as the state of art of its related technologies and its connection process to the electrical grid.
\end{abstract}

KeYwords: Electricity, Home Networks, Learning, Mini Courses, Photovoltaic Systems. 


\section{INTRODUCTION}

The increasing of the electrical demand in Brazil as well as the lack of hydric resources to further hydroelectric expansions increase the need of new sources of energy mainly the clean and renewable such as the wind energy, photovoltaic, biomass and geothermal [1].

Considering the huge size of the Brazilian territory and it very high solar incidence, the photovoltaic energy arises as an important source of electrical energy. However, it's participation in the whole Brazilian electrical matrix is small, mainly due to the lack of public benefits and too early regulations towards the local energy providers.

The deployment of photovoltaic systems tends to nationally increase in Brazil. Based on researches, it was deployed, till March 2018 Brazil had 20,897 installed systems, being expected figures of approximately 887,000 in 2024 [2].

In face of this mentioned scenario it's inevitable that labors to project and installations of photovoltaic systems, the young public from schools understanding and specializing in mini courses about those topics. Those mini courses enclose many important contents such as:

1. Solar energy generation: Presents an introduction about the operation principle of cells, photovoltaic modules as well as grid integrated photovoltaic systems;

2. Solar energy introduction: Present the state of art of photovoltaic systems integrated or not into the electrical grid, besides the proper dimension of the elements in the system;

3. Photovoltaic system: Presents a photovoltaic project with the proper dimensions of modules, inverters, conductors, protectors as well as the documentation provided to the energy supply in order to get the project approval;

\section{Methodology}

The photovoltaic system itself produces electricity from the solar luminosity and can also run in cloudy and rainy days. It's also necessary to take in mind that bigger the solar irradiation, bigger will electricity production. This energy is 
produced throw the conversion of solar energy in electricity, the photovoltaic cell being assembled with semiconductor material [3], the fundamental unit of this conversion process as in the Fig. 1.

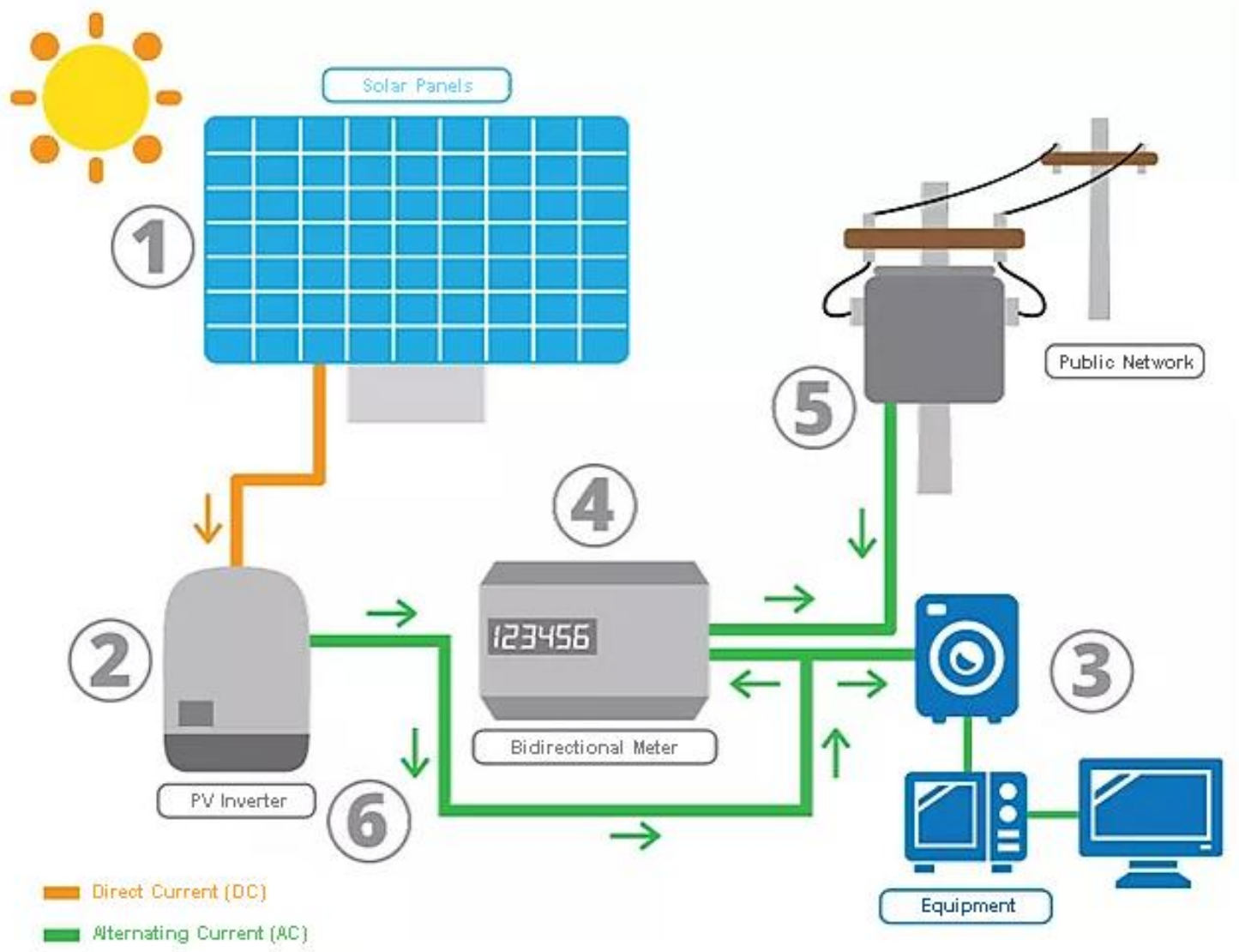

Fig. 1. Example operation of the photovoltaic energy system.

The complete system has two main steps, the solar panels and the inverters. The panels are the system's key, and, when exposed to solar light, it generates electricity. The inverter is the system's brain, automatically synchronizing with the grid, assuring the priority use of the solar energy over the energy from the public grid [4][5].

The first mini course (solar energy generation) is offered to the students of enrolled schools in the deployment of this project and it has the intention of spread the knowledge about photovoltaic energy generation, widening the knowledge till the society, demonstrating the main sources of renewable energies. This course is, though, focused in the photovoltaic electrical energy generation [6]. 
The training is run in an appropriate place, such as an engineering laboratory or large classrooms with appropriate computers. The development of activities is performed throw the creation of small groups, favoring the teamwork, improving the development of the data gathering and analysis [7].

The course content is composed of the presentation of the main types of renewable sources of energy, working principles of cells and modules and the explanation of photovoltaic modules, connected or unconnected to the local electrical grid.

All the mini courses steps are composed of a theorical part and a practical one, whom the students may use the photovoltaic didactic kit, as in the Fig. 2.

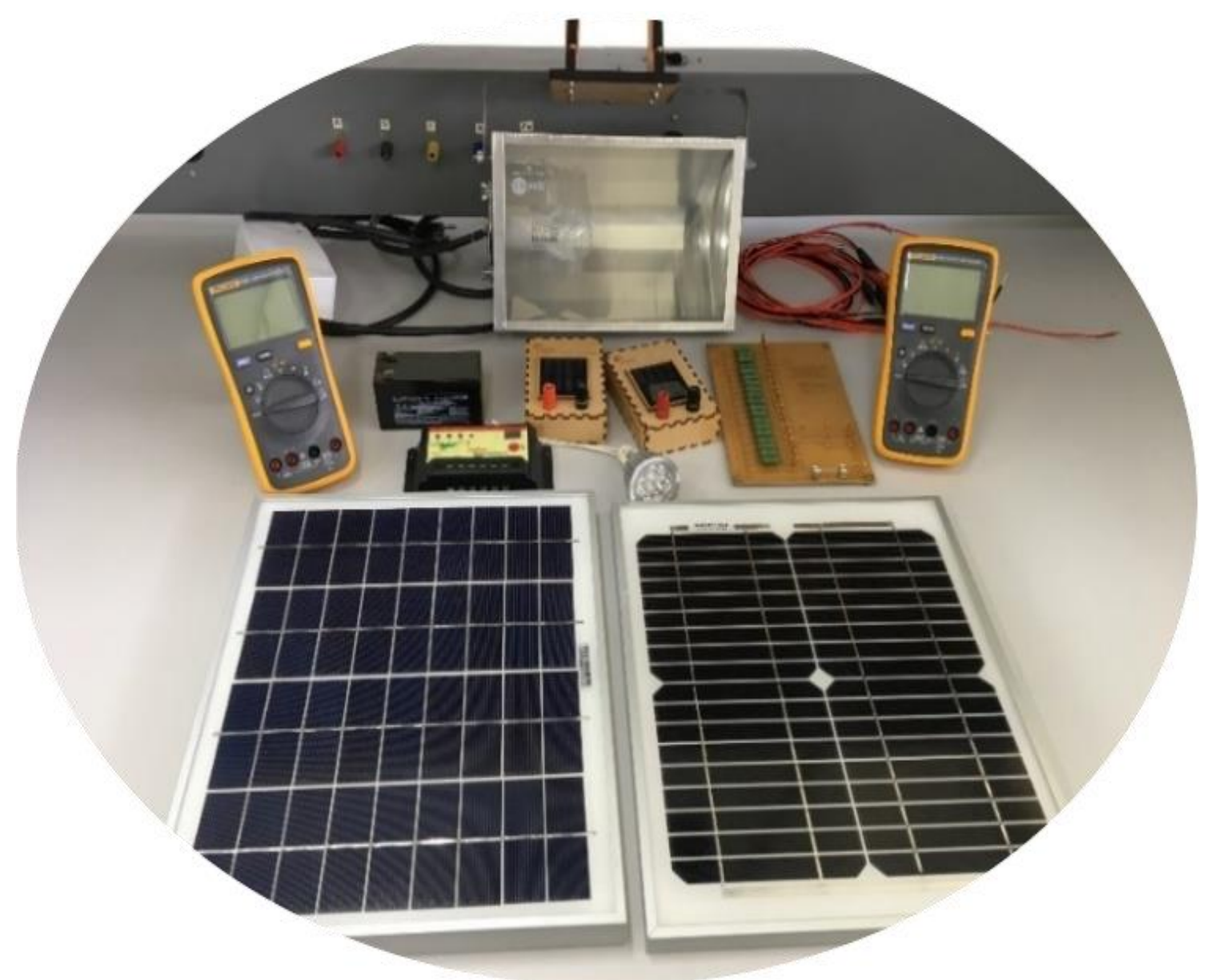

Fig. 2. Didactic kit for mini courses.

In the kit, there's some developed items from the professors themselves such as the charge board made of resistors, the enclosures and the luminary which will simulate the solar light. The rest is separately bought in electrical stores or in specific websites. The complete kit is made of the following items: 
1. 1un Monocrystalline photovoltaic module;

2. 1un Polycrystalline photovoltaic module;

3. 2un Thin film photovoltaic cells;

4. 2un Digital multimeters;

5. 1un 100W luminary;

6. 1un Charge controller;

7. 1un $12 \mathrm{~V} / 3 \mathrm{Ah}$ battery;

8. 1un Resistors charge boards;

9. 1 1un 3W LED lamp;

In the practical side, the students assemble the experiments with the help of a teacher and using the thin film photovoltaic cells. The goal of this installation is the data survey in order to plot the power versus voltage pattern graphic of both, a single and of two cells.

In this procedure the student set and keeps the luminosity source in the maximum intensity after changing the resistance values in the charge board. The verified values in the voltmeter and the ammeter are later noted in a table in order to lately plot the correspondent graphics [8][9].

In this step of the mini course are presented to the students the concepts of voltage, amperage and power. There are also presented the circuit assembly and the necessary electric connections to the circuits. After the theoretical study of the photovoltaic cells, the students will study the behavior of two photovoltaic modules of $10 \mathrm{pW}$ each, one of them, monocrystalline and the other, polycrystalline.

In those two experimental procedures it's expected from the students to plot the typical curve of the photovoltaic modules. Towards them, it's explained to the students the open circuit, the short-circuit current and the maximum power point of a studied cell or photovoltaic modules.

\section{A. Course Evaluations}

In the end of the mini course the students must submit a written evaluation fill a formulary. The main questions are related to the course's objectives as well as questioning if the workload was enough and if they would indicate the course to other people. The answers are visualized in the Fig. 3, Fig. 4 and Fig. 5. 
- Excellent $=$ Good = Regular $=$ Bad

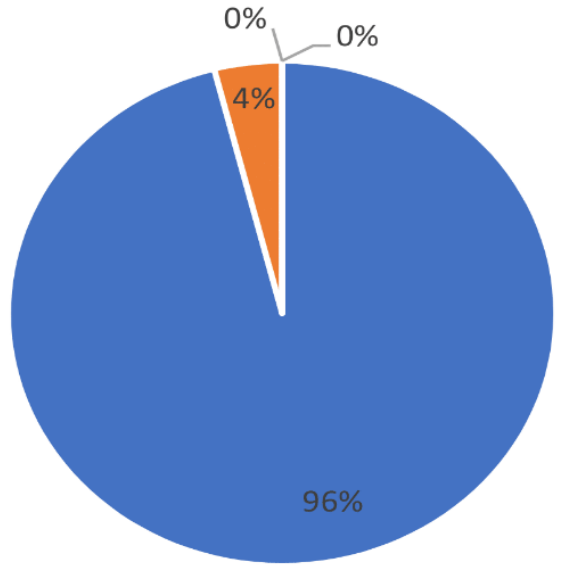

Fig. 3. Feedback: Learning Objectives.

- Excellent " Good = Regular $\|$ Bad

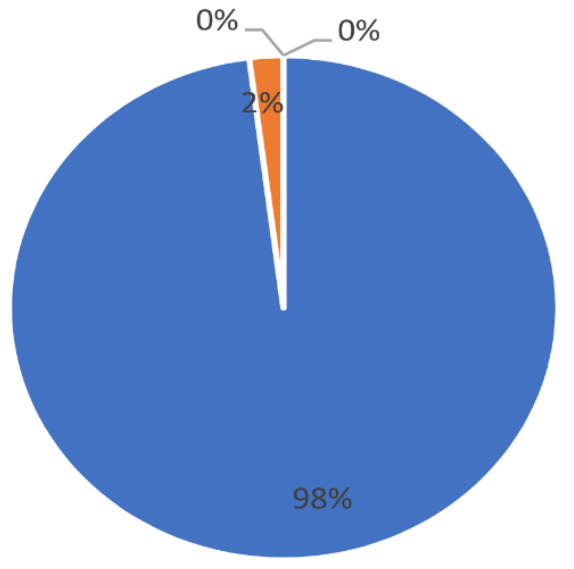

Fig. 4. Feedback: Hours.

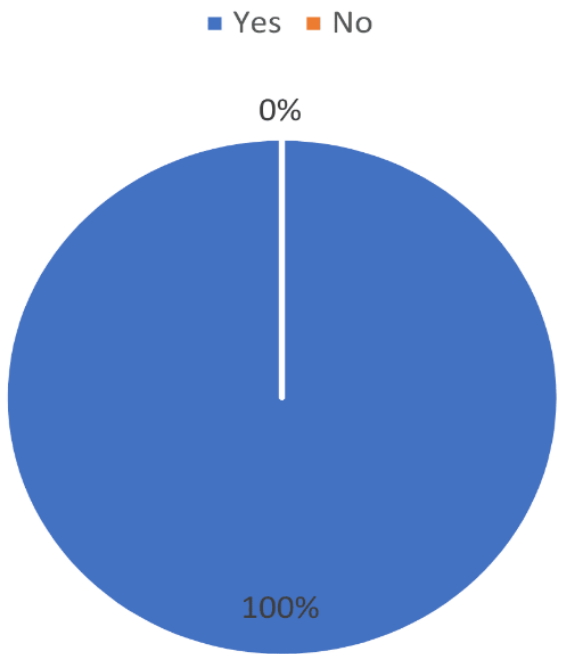

Fig. 5. Feedback: Indication. 
As noticed, the learning goals of the course were achieved since $96 \%$ of the participants evaluated the course as excellent and $4 \%$ as good. About the workload, it was considerate ideal, $98 \%$ getting an excellent evaluation, $2 \%$ good and $100 \%$ recommending the course to others. These answers were obtained in survey with 202 students between the November/2019 and February/2020.

\section{CONCLUSION}

The entire developed project in the training mini courses to the youth and destined to the schools having as goal the dissemination of the photovoltaic electrical energy generation. The students' participations demonstrate that the mini courses are reaching their learning goals and bringing knowledge to the society.

Moreover, the mini courses have the function of motivating the students to search new knowledge in the area, mainly about renewable energies, presenting themselves a very big growing potential, not just in Brazil, but worldwide. 


\section{REFERENCES}

[1] R. C. Torres, "Energia solar fotovoltaica como fonte alternativa de geração de energia", SP: São Carlos, Universidade de São Paulo, 2012.

[2] Equipe eCycle, "Poderia toda a energia do mundo ser obtida pela radiação solar?". Available at: <https://www.ecycle.com.br/component/content/article/37-tecnologia-a-favor/3095-pode ria-toda-a-energia-do-mundo-ser-obtida-por-energia-solar.html>. Accessed: 30 May 2020.

[3] R. Zilles, "Energia fotovoltaica", SP: São Paulo, USP, 2012. Available at: <http://www.iee.usp.br/sites/default/files/biblioteca/producao/2012/Livros/zillesenergiasolar. pdf>. Accessed: 30 May 2020.

[4] A. M. Vallera, M. C. Brito. "Meio século de história fotovoltaica", Faculdade de Ciências da Universidade de Lisboa, Lisboa: Campo Grande, 2006. Available at: <http://solar.fc.ul.pt/gazeta2006.pdf>. Accessed: 30 May 2020.

[5] Ambiente Energia. "Nova célula solar tem eficiência de 44,5\%, a maior do mundo", Ambiente Energia, 2017. Available at: <https://www.ambienteenergia.com.br/index.php/2017/07/novacelula-solar-tem-eficiencia-de-445-maior-mundo/32187\#.W8UnuyyJLIU>. Accessed: 30 May 2020.

[6] J. Jones. "Nova célula solar fotovoltaica promete a maior eficiência de sempre", 2017. Portal Energia. Available at: <https://www.portal-energia.com/celula-solar-fotovoltaica-maioreficiencia>. Accessed: 30 May 2020.

[7] C. A Santos. "As digitais de Einstein em nosso cotidiano", 2008. Universidade Estadual do Rio Grande do Sul. Available at: <http://cienciahoje.org.br/coluna/as-digitais-de-einstein-emnosso-cotidiano>. Accessed: 30 May 2020.

[8] I. C. Moreira. "Einstein e seus Trabalhos de 1905 e 1915", UFRJ. Available at: <http://www.educacaopublica.rj.gov.br/biblioteca/fisica/0004.html>. Accessed: 30 May 2020.

[9] C. A. Santos. "O Prêmio Nobel de Einstein", 2004. Available at: $<$ http://www.if.ufrgs.br/einstein/efeitofotoeletricopremionobel.html>. Accessed: 30 May 2020. 


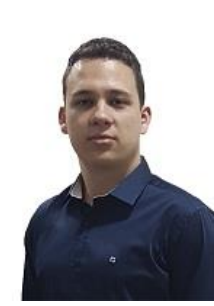

Daniel Rodrigues Ferraz Izario. Electrical Engineer doctoral student from University of Campinas in Campinas/SP - Brazil from August/2019 to January/2022. Specialized in Business Engineering at the International University Center in Indaiatuba/SP - Brazil from July/2019 to April/2020. Master's degree in Electrical Engineer at University of Campinas in Campinas/SP - Brazil from August/2017 to August/2019. Bachelor's degree in Computer Engineering at National Institute of Telecommunications in Santa Rita do Sapucai/MG - Brazil from January/2012 to July/2017, with a sandwich degree at Porto University in Porto/Portugal from January/2015 to July/2015. Computer technician at the Milton Ballerini SENAI vocational school in Lorena/SP - Brazil from March/2008 to December/2010. He acts mainly in four areas: 1. "Technician Leader", managing the whole team and the project; 2. "Author/Contenist" of subjects and contents focused educational integrated solutions in education, communication and technology, generating innovative results to multiple learning institutions, companies and business; 3. "Periodic/Article Reviewer" (AIPSCSA, ISUAVs and BTSym); 4. "Scientific Researcher" with interests in financial systems, audio/data/image processing, games, 2D/3D animations, artificial intelligence, neural networks, data transmission/storage, safety/defense, smart cities, 4.0 industry, pattern recognition and agile methodology, focused in the following technologies: Angular 2+, Javascript and .Net Core.

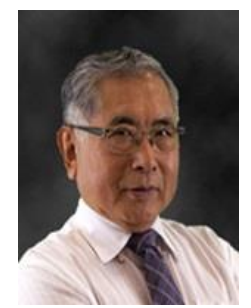

Yuzo lano. Has graduation (1972), master's degree (1974) and PhD (1986) University of Campinas in Campinas/SP - Brazil . In the present time is MS6 Full Professor in the DECOM/FEEC/UNICAMP - Communications Department of the Electrical and Computer Engineer from UNICAMP, chief editor of the SET International Journal of Broadcast Engineering and general president of the BTSym - Brazilian Technology Symposium. He has experiences in the Electrical Engineering field, with emphasis in Telecommunications, Electronics and Information Technology fields and had acted mainly in data and audiovisual fields. His key interests are processing and digital transmission of signals/images/audio/data, HDTV, digital TV, 3G/4G/5G networks, patterns recognition, digital signal codification, data transmission and storage, wireless sensors networks, photovoltaic solar energy generation prediction systems and smart/digital cities.

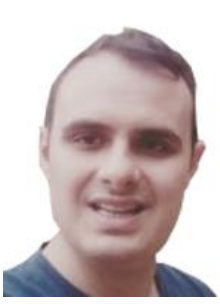

João Luiz Brancalhone Filho. Bachelor in Telecommunications Engineering from National Institute of Telecommunications in Santa Rita do Sapucai/MG Brazil from January/2012 to December/2019 with a sandwich degree in the Jade University in Wilhelmshaven/Germany from July/2014 to July/2015. Intern in the Mobile Networks area at INATEL and in the Ciena Communications at the Sales Engineering area, also performing activities along with Project Management and deployment teams. Scientific researcher, with interest in mobile, $3 G / 4 G / 5 G$ networks, LTE, digital transmission of signals/images/videos/audio/data, digital TV and smart/digital cities.

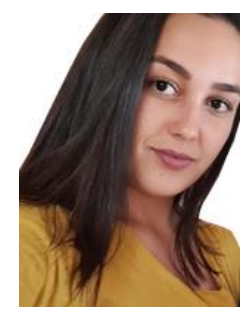

Karine Mendes Siqueira Rodrigues Ferraz Izario. Undergraduate in pedagogy from the Anhanguera College, Indaiatuba/SP - Brazil, from January/2020 to December/2024. Nurse technician in the Colégio Osvaldo Cruz - COC in São Lourenço/MG - Brazil from February/2014 to March/2016. Intern in the "Hospital da Fundação Casa de Caridade de São Lourenço" and "Centro Viva Vida" in São Lourenço/MG. Scientific researcher with main interests in technologies, learning, affectivity and cognition as mediation towards education; studentprofessor relations; 2D/3D animations; artificial intelligence and neural networks. 